\title{
Cost-benefit analysis of neuromuscular blocking agents
}

Health care costs are perceived by many, including hospital administrators, politicians and the general public, as spiralling upwards and out of control. All areas of medicine, especially the fast evolving, high technology specialities, such as anaesthesia, are viewed as major contributors to the escalating costs. This perception, coupled with the reluctance of governments and taxpayers to increase their contributions to health care, has increased the pressure on physicians to consider cost when managing patients. There is obvious reluctance on the part of doctors to compromise patient care in the name of budgetary constraints, but it is no longer possible to ignore the problem. In the future, accountability will not only mean patient safety and satisfaction, but also optimal use of unfortunately scarce resources. As anaesthetists, we will either have to find more frugal ways to practise, or to justify our expenses.

\section{The problem}

\section{Neuromuscular blocking drugs}

Muscle relaxation is an important component of anaesthesia, and neuromuscular blocking drugs are administered commonly for the purpose of providing immobility of patients under general anaesthesia. The drugs used for this purpose have a wide range of prices and properties, so potential drug savings can be made by switching from one drug to another. However, these drugs represent a small fraction of the cost of anaesthesia and surgery. In one study performed in Ottawa, ${ }^{1}$ neuromuscular blocking drugs and their antagonists represented less than $23 \%$ of the anaesthetic drug budget. In turn, drugs used in anaesthesia represented only $5.7 \%$ of the hospital pharmacy budget, and only $0.3 \%$ of the total hospital budget. In this example, neuromuscular blocking drugs in anaesthesia amounted to less than $0.07 \%$ of the hospital budget. This small amount does not discharge anyone from the responsibility of trying to restrain costs, but one needs to look at the potential increase in costs in other areas if cheaper, second-line drugs are used.

\section{Who pays, who saves, and who benefits?}

The major problem in carrying out a cost-benefit analysis is to identify who bears the cost and who stands to benefit.
Johnstone and Martinec ${ }^{2}$ demonstrated the complexity of interactions between patients, providers, payers and facilities. Even in a "single payer" type system, such as exists in Canada, it is not always easy to determine if any intervention is cost-effective. For example:

1 Savings in one "cost centre" with a small budget might result in larger, but less easily identifiable expenditures for another "cost centre." For instance, switching from an intermediate-acting drug to a longer-acting drug might save drug costs, but the average length of stay of patients in the recovery room might be longer. The costs associated with the longer stay will be difficult to attribute directly to the neuromuscular blocking drug, and might not be identified because the recovery room budget is greater than the anaesthetic drug budget.

2 Some savings become apparent only when a large number of anaesthetists and other health care workers adopt the same consistent policy. An illustration of this is the potential savings brought about by short-acting drugs because of increased turnover. The benefits of costly short-acting drugs cannot be seen unless surgeons, nurses and orderlies cooperate to decrease turnover time. Another example would be the use of shorter-acting, more expensive drugs by one individual in a large group of anaesthetists. A significant decrease in mean recovery room stay and significant savings will obviously not be achieved by this individual's contribution.

3 Patients' dissatisfaction has a cost, but it rarely appears in the hospital's balance sheet. For example, it is difficult to put a price tag to the occurrence of annoying muscle pains, or impaired cough, or unsteady gait in an outpatient.

4 Substantial savings can be generated by a shorter stay in the operating room and the recovery room. In Winnipeg, recovery room costs were evaluated to be $\$ 876,306$ for 8458 surgical casts, or $\$ 103$ per patient. ${ }^{3}$ Although the average stay in the recovery room was not specified, the cost was probably of the order of

From the McGill Department of Anaesthesia, Royal Victoria Hospital, 687 Pine Avenue West, Montreal, PQ H3A 1Al. 
$\$ 1$ per minute. Operating room time is even more expensive. In our institution, labour and maintenance costs amount to approximately $\$ 2$ per minute. Thus, a rapid onset, easily reversible relaxant which could "save" only five minutes in the operating room and shorten recovery room stay by only ten minutes could potentially save $\$ 20$ per case. The hospital might not, however, benefit from these savings if the number of nurses in the recovery room remains unchanged, if the anaesthetist sits down for an extra coffee between cases, or if the time saved during the day is only an opportunity for the operating room staff to go home early.

Unfortunately, very few studies have addressed the issues above, and the various considerations outlined above make it difficult to reach definite conclusions. Nevertheless, a good place to start is to determine the cost of providing muscle relaxation and reversal.

\section{Cost of neuromuscular blocking agents}

\section{Fixed costs}

In Canada, drugs given in a hospital setting are not charged to the patient or to a third payer (the government). The hospital pharmacy is responsible for purchasing, storing, in some cases preparing, and supplying the drugs administered by anaesthetists. These fixed costs will not be considered here because substitution of one drug by another does not normally produce any savings.

\section{Costs associated with drug administration}

In anaesthesia, drugs are administered by the anaesthetist, who must be present near the patient at all times. Thus, no cost savings can be realized by changing the method or frequency of administration. The cost of syringes and needles is usually small compared with the cost of drugs (a $10 \mathrm{ml}$ syringe and a 20 ga needle cost $\$ 0.10$ ). Infusions are more expensive, but reasonably affordable. A $60 \mathrm{ml}$ syringe, plus connector, plus stopcock cost less than $\$ 1.00$. Finally, the most important factor might be cracking the ampoule open. The cost of vecuronium is the same (\$19.49) whether all or part of the $10 \mathrm{mg}$ available in the vial is used.

\section{Changing costs}

Drug prices vary, sometimes widely, from year to year and from country to country, if not from hospital to hospital. Some reasons for these variations are (1) marketing forces; (2) bulk purchases; (3) presence of a competitor; (4) availability of a generic formulation. Thus, any cost consideration must be made for each institution, knowing the prices paid by that particular institution, and the conclusions must be revised periodically. For example, at the time of writing (end of 1993) pancuronium
TABLE I

\begin{tabular}{lcc}
\hline Drug & Amount & Cast (SCan) \\
\hline Succinylcholine & $100 \mathrm{mg}$ & 0.88 \\
Succinylcholine powder & $500 \mathrm{mg}$ & 7.34 \\
Atracurium & $100 \mathrm{mg}$ & 39.55 \\
Vecuronium & $10 \mathrm{mg}$ & 19.49 \\
Pancuronium & $5 \mathrm{mg}$ & 6.60 \\
d-Tubocurarine & $30 \mathrm{mg}$ & 1.06 \\
Doxacurium & $5 \mathrm{mg}$ & 26.15 \\
Metocurine & $40 \mathrm{mg}$ & 22.88 \\
Mivacurium & $20 \mathrm{mg}$ & $20.00^{*}$ \\
Rocuronium & $\mathrm{n} / \mathrm{a}$ & $\mathrm{n} / \mathrm{a}$ \\
Atropine & $0.6 \mathrm{mg}$ & 0.21 \\
Glycopyrrolate & $4 \mathrm{mg}$ & 10.40 \\
Neostigmine & $5 \mathrm{mg}$ & 2.06 \\
Edrophonium & $100 \mathrm{mg}$ & 5.72 \\
\hline
\end{tabular}

*Based on U.S. prices. The drug was not available in Canada at the time of writing.

was available at our hospital for $\$ 6.60$ for $5 \mathrm{mg}$ ( $\$ 1.34$ per $\mathrm{mg}$ ). In Kansas, the 1993 price for the same drug was quoted as US $\$ 1.66$ per $10 \mathrm{mg}$, or less than US\$0.17 per mg. ${ }^{4}$ Table I lists the costs of drugs, in Canadian dollars, available at the Royal Victoria Hospital, in Montreal, at the end of 1993. This should give an indication, but only an indication, of the prices prevailing at other Canadian hospitals.

\section{Cost of producing, maintaining, and reversing paralysis}

The following will focus on the cost of establishing adequate blockade for tracheal intubation, maintaining sufficient paralysis, and restoring neuromuscular function, if required, at the end of the surgical procedure. The total cost will depend on the agent used, the dose given, the duration of the procedure, and of course the weight of the patient.

\section{Intubating dose}

The dose required for tracheal intubation is at least twice the dose corresponding to that producing $95 \%$ blockade at the adductor pollicis. The reasons for using relatively high doses are (1) interindividual variability, which implies that many patient will not be adequately blocked by an $\mathrm{ED}_{95}$ dose; $^{5}$ and (2) the relative resistance of laryngeal ${ }^{6}$ and respiratory ${ }^{7}$ muscles to the effect of relaxants. Table II lists the $\mathrm{ED}_{95}{ }^{8-12}$ for the various relaxants available in Canada and the cost for a $70 \mathrm{~kg}$ patient. Succinylcholine, in spite of its numerous side effects, remains the least expensive choice. Using a defasciculating dose of a non-depolarizing agent increases succinylcholine requirements, ${ }^{9}$ but the technique remains inexpensive. If a long-acting relaxant is chosen, only d-tubocurarine remains relatively inexpensive. However, most clinicians would be reluctant to use such large doses of $d$ - 
TABLE II

\begin{tabular}{llll}
\hline Drug & $\begin{array}{l}E D_{95} \\
\left(\mathrm{mg} \cdot \mathrm{kg}^{-1}\right)\end{array}$ & $\begin{array}{l}2 \times E D_{95} \text { per } 70 \mathrm{~kg} \\
(\mathrm{mg})\end{array}$ & $\begin{array}{l}\text { Cost } \\
(\$ \mathrm{Can})\end{array}$ \\
\hline $\begin{array}{l}\text { Succinylcholine } \\
\text { d-Tubocurarine plus }\end{array}$ & 0.5 & 70 & 0.62 \\
$\quad$ succinylcholine & 1.0 & $140(+3 \mathrm{mg} \mathrm{dTC})$ & 1.55 \\
Atracurium & 0.25 & 35 & 13.84 \\
Vecuronium & 0.05 & 7 & 13.64 \\
Pancuronium & 0.07 & 10 & 13.20 \\
d-Tubocurarine & 0.4 & 50 & 1.99 \\
Doxacurium & 0.03 & 4.2 & 21.94 \\
Metocurine & 0.2 & 14 & 16.02 \\
Mivacurium & 0.1 & 14 & $14.00^{*}$ \\
Rocuronium & 0.3 & 42 & $\mathrm{n} / \mathrm{a}$ \\
\hline
\end{tabular}

*Based on U.S. prices. The drug was not available in Canada at the time of writing.

tubocurarine because of the histamine release potential. The major problem with long-acting drugs is that the duration of action often exceeds the duration of the surgery. Reversal might also be problematic in some cases. ${ }^{5,13}$

\section{Maintenance of relaxation}

The duration of action of an intubating dose until further relaxation is required depends on the type of neuromuscular blocking drug given initially. With succinylcholine, another loading dose is required when neuromuscular blockade wears off, that is 5-15 min after the initial dose. If a non-depolarizing relaxant is used in this setting, an $\mathrm{ED}_{95}$ dose will be required. Mivacurium recovers usually within 15-25 min. ${ }^{10}$ Intubating doses of atracurium, vecuronium, or rocuronium will produce greater than $90 \%$ paralysis for 20-50 min. ${ }^{14,15}$ Equipotent doses of the longacting neuromuscular blocking drugs will produce the same effect for 30-180 min. ${ }^{14}$ When spontaneous recovery is manifest, the doses required to maintain the effect are listed in Table III. ${ }^{10,15-18}$

\section{Reversal}

It is customary to use a standard dose for reversal of neuromuscular blockade in all patients. Table IV lists the costs associated with the most common mixtures. It should be remembered, however, that these doses (or even higher doses) are insufficient for profound blockade, ${ }^{5,13}$ and that smaller doses might be just as effective when blockade is not profound. ${ }^{19}$

\section{Total cost of relaxation-reversal}

The total cost for a whole procedure depends on the agents used and the duration of the case. The choice of drug is not limited only by cost, but also by the unpredictability of the drug and cardiovascular effects. It
TABLE III

\begin{tabular}{|c|c|c|c|}
\hline \multirow[b]{2}{*}{ Drug } & \multicolumn{2}{|c|}{ Infusion rate } & \multirow{2}{*}{$\begin{array}{l}\text { Cost for } 70 \mathrm{~kg} \\
\text { per } \mathrm{hr} \text { (\$Can) }\end{array}$} \\
\hline & $(\mu g \cdot k g$ & $\left(m g \cdot \mathrm{kg}^{-1}\right)$ & \\
\hline Succinylcholine & 100 & 420 & 6.17 \\
\hline Atracurium & 5 & 21 & 8.31 \\
\hline Vecuronium & 1 & 4.2 & 8.19 \\
\hline Rocuronium & 7 & 29.4 & $n / a$ \\
\hline Mivacurium & 7 & 29.4 & $29.40^{*}$ \\
\hline Pancuronium & 0.4 & 1.7 & 2.24 \\
\hline d-Tubocurarine & 3 & 12.6 & 0.45 \\
\hline Metocurine & 1.5 & 6.3 & 3.60 \\
\hline Doxacurium & 0.15 & 0.63 & 3.29 \\
\hline
\end{tabular}

* Based on U.S. prices. The drug was not available in Canada at the time of writing.

TABLE IV

\begin{tabular}{lll}
\hline Drugs & $\begin{array}{l}\text { Dose (for 70 kg person) } \\
(\mathrm{mg})\end{array}$ & $\begin{array}{l}\text { Cost } \\
\text { (SCan) }\end{array}$ \\
\hline Atropine-neostigmine & $1.2-2.5$ & 1.45 \\
Glycopyrrolate-neostigmine & $0.6-2.5$ & 2.59 \\
Atropine-edrophonium & $0.6-30$ & 1.93 \\
\hline
\end{tabular}

is probably safe to state that the neuromuscular effect of a given dose on an individual patient may be as little as that expected from half the dose, or as much as twice the dose. Stated another way, the duration of pancuronium, $10 \mathrm{mg}$, may be as little as the mean duration produced by $5 \mathrm{mg}$, or $30 \mathrm{~min}$, or as long as that of $20 \mathrm{mg}$, or $180 \mathrm{~min}$. Because doubling the dose is associated with less increase in duration for intermediateand short-duration drugs, relaxants such as vecuronium, atracurium, and mivacurium are more predictable. Table $V$ shows cost comparisons for cases of different durations. The least expensive technique for short cases is a succinylcholine bolus followed by an infusion. Long-acting relaxants are not recommended for short procedures. For long cases, intubation with succinylcholine and maintenance with a cheap long-acting drug is least expensive. This, however, must be balanced against the side effects of succinylcholine and those of long-acting relaxants, plus the problems encountered in reversing long-acting drugs.

\section{Cost management strategies}

The cost of all neuromuscular blocking drugs is small compared with the total cost of hospitalization. Thus, if a relaxant is needed, it is better to give it. However, attention to simple measures may help cut costs:

1 Waste. A drug which left unused does not benefit anyone. Expensive muscle relaxants should be prepared immediately before use, only in the quantity required. 
TABLE V Cost comparisons for a typical $70 \mathrm{~kg}$ patient (I: induction; M: maintenance; R: reversal)
Duration: $30 \mathrm{~min}$
I: $\quad$ TTC (3 mg), succinylcholine $(140 \mathrm{mg})$
$\mathrm{M}$ : Succinylcholine $(200 \mathrm{mg})$
R: Nil
I: $\operatorname{dTC}(3 \mathrm{mg})$, succinylcholine (140 mg)
M: Vecuronium ( $3 \mathrm{mg}$ ) or atracurium (15 mg)
R: Atropine (1.2 mg), neostigmine $(2.5 \mathrm{mg})$
I: Vecuronium (7 mg) or atracurium (35 mg)
M: Nil
$\mathrm{R}$ : Atropine $(1.2 \mathrm{mg})$, neostigmine $(2.5 \mathrm{mg})$

(N.B. Vecuronium or atracurium for intubation will frequently have a duration of action too long for the case)

Duration: $60 \mathrm{~min}$

I: dTC (3 mg), succinylcholine (140 mg)

M: Succinylcholine $(500 \mathrm{mg})$

R: Nil

I: $\quad$ dTC (3 mg), succinylcholine ( $140 \mathrm{mg})$

$\mathrm{M}$ : Vecuronium $(5 \mathrm{mg})$ or atracurium $(25 \mathrm{mg})$

$\mathrm{R}$ : Atropine $(1.2 \mathrm{mg})$, neostigmine $(2.5 \mathrm{mg})$

I: Vecuronium (7 mg), or atracurium $(35 \mathrm{mg})$

M: Vecuronium ( $2 \mathrm{mg})$, or atracurium $(10 \mathrm{mg})$

$\mathrm{R}$ : Atropine $(1.2 \mathrm{mg})$, neostigmine $(2.5 \mathrm{mg})$

I: $\operatorname{dTC}(3 \mathrm{mg})$, succinylcholine (140 mg)

M: Pancuronium $(5 \mathrm{mg})$

R: Atropine (1.2 mg), neostigmine $(2.5 \mathrm{mg})$

(N.B. Reversal of pancuronium might be incomplete)

Duration: $120 \mathrm{~min}$

I: $\operatorname{dTC}(3 \mathrm{mg})$, succinylcholine (140 mg)

M: Succinylcholine $(1200 \mathrm{mg})$

$\mathrm{R}$ : Atropine ( $1.2 \mathrm{mg}$ ), neostigmine ( $2.5 \mathrm{mg}$ )

I: $\quad$ dTC (3 mg), succinylcholine ( $140 \mathrm{mg}$ )

M: Vecuronium $(10 \mathrm{mg})$ or atracurium $(50 \mathrm{mg})$

I: Vecuronium $(7 \mathrm{mg})$, or atracurium $(35 \mathrm{mg})$

M: Vecuronium $(7 \mathrm{mg})$, or atracurium $(35 \mathrm{mg})$

R: Atropine (1.2 mg), neostigmine ( $2.5 \mathrm{mg})$

M: Pancuronium (7 mg)

R: Atropine (1.2 mg), neostigmine (2.5)

I: $\operatorname{dTC}(3 \mathrm{mg})$, succinylcholine (140 mg)

M: dTC (30 mg)

$\mathrm{R}$ : Atropine (1.2 mg), neostigmine (2.5)

I: Pancuronium (10 mg)

M: Nil

$\mathrm{R}$ : Atropine (1.2 mg), neostigmine (2.5 mg)

I: $\operatorname{dTC}(3 \mathrm{mg})$, succinylcholine $(140 \mathrm{mg})$

M: Doxacurium $(2.5 \mathrm{mg})$

R: Atropine (1.2 mg), neostigmine ( $2.5 \mathrm{mg})$

$\$ 16.08$
R: Atropine $(1.2 \mathrm{mg})$, neostigmine $(2.5 \mathrm{mg})$

I: dTC (3 mg), succinylcholine (140 mg)

A $10 \mathrm{ml}$ syringe plus a needle cost only $\$ 0.10$. There might be advantages in drawing up the drug into several syringes.

2 Give only the amount required. It is usually not necessary to paralyze beyond one visible twitch (monitor!). Certain (superficial and peripheral) procedures require less relaxation, or none at all. Do not maintain paralysis if a tourniquet is used (the relaxant will not reach the surgical site!).

\section{Pitfalls}

There are, however, some well-intentioned manoeuvres which may not pay off in the end, such as:

1 Relying on mutual potentiation. When used in pairs, some relaxants potentiate each other. The most classic example is the pancuronium-metocurine mixture. ${ }^{20} \mathrm{Al}$ though dosage can be reduced considerably, the high cost of metocurine makes the proposition uninteresting. Pancuronium and d-tubocurarine also potentiate each other, ${ }^{20}$ but the cost of the mixture is greater than the cost of d-tubocurarine alone, even used in larger doses. Atracurium and vecuronium appear to have a slight potentiating effect on each other, ${ }^{21}$ but this has not been consistent in all studies. Finally, dtubocurarine and vecuronium potentiate each other, ${ }^{22}$ but the mixture probably does not retain the fast recovery profile of vecuronium.

2 Giving a long-acting drug after an intermediate-acting drug. If a procedure turns out to be longer than anticipated, it is tempting to give, say, pancuronium after vecuronium. In this case, the duration of action of the "long-acting" relaxant is more like that of the "intermediate-acting" relaxant. ${ }^{23}$ Thus, little is saved if both agents have comparable prices.

3 Switching systematically to long-acting relaxants. Older, long-acting (and cheaper) relaxants may lead to more problems than the cost savings they generate.

(N.B. Reversal of pancuronium, dTC and doxacurium might be incomplete)
Residual paralysis is common after these agents, 5,13 their duration of action is more unpredictable, and the intensity of paralysis that one can achieve safely is less than for shorter-acting drugs.

4 Avoiding reversal. The cost of usual doses of glycopyrrolate and neostigmine is only $\$ 2.59$. With atropine, reversal is even less expensive. Reduced doses of reversal agents are recommended when recovery from paralysis is almost complete. However, because of the high cost of caring for respiratory depression, reversal is mandatory, unless there is convincing evidence that neuromuscular function has recovered completely.

5 Avoiding relaxation altogether. Compared with modern muscle relaxants, intravenous and inhalational anaesthetic drugs produce much greater cardiovascular effects. Failure to administer relaxants may produce 
an increased requirement of anaesthetic drugs, which may increase cost and delay awakening.

\section{Conclusion}

At present, the cost of muscle relaxants is too small compared with other costs of anaesthesia, surgery, and hospital stay, to suggest that any patient should be denied their benefits on the basis of cost alone. Substituting newer relaxants for cheaper alternatives may sometimes introduce significant problems. However, significant savings could be generated by avoiding waste and overtreatment.

\section{References}

1 Torsher L, Martineau RJ, Tierney M, Hopkins HS, Miller $D R$. A survey of anaesthetic drug expenditures. Can J Anaesth 1992; 39: A113.

2 Johnstone RE, Martinec CL. Costs of anesthesia. Anesth Analg 1993; 76: 840-8.

3 Hudson RJ, Friesen RM. Health care "reform" and the costs of anaesthesia (Editorial). Can J Anaesth 1993; 40: 1120-5.

4 Becker $K E$. Cost containment in anesthesiology: how much is too much? ASA Newsletter 1993; 57 (10): 5-8.

5 Katz RL. Neuromuscular effects of d-tubocurarine, edrophonium and neostigmine in man. Anesthesiology 1967; 28: $327-36$.

6 Donati F, Meistelman C, Plaud B. Vecuronium neuromuscular blockade at the adductor muscles of the larynx and adductor pollicis. Anesthesiology 1991; 74: 833-7.

7 Donati $F$, Antzaka C, Bevan DR. Potency of pancuronium at the diaphragm and the adductor pollicis muscle in humans. Anesthesiology 1986; 65: 1-5.

8 Shanks $C A$. Pharmacokinetics of the nondepolarizing neuromuscular relaxants applied to calculation of bolus and infusion dosage regimens. Anesthesiology 1986; 64: $72-86$.

9 Szalados JE, Donati F, Bevan DR. Effect of d-tubocurarine pretreatment on succinylcholine twitch augmentation and neuromuscular blockade. Anesth Analg 1990; 71 : 55-9.

10 Diefenbach C, Mellinghoff $H$, Lynch J, Buzello W. Mivacurium: dose-response relationship and administration by repeated injection or infusion. Anesth Analg 1992; 74: 420-3.

11 Koscielniak-Nielsen ZJ, Law-Min JC, Donati F, Bevan $D R$, Clement $P$, Wise $R$. Dose-response relations of doxacurium and its reversal with neostigmine in young adults and healthy elderly patients. Anesth Analg 1992; 74 : 845-50.

12 Bevan DR, Fïset P, Balendran P, Law-Min JC, Ratcliffe $A$, Donati $F$. Pharmacodynamic behaviour of rocuronium in the elderly. Can J Anaesth 1993; 40: 127-32.
13 Bevan DR, Donati F, Kopman AF. Reversal of neuromuscular blockade. Anesthesiology 1992; 77: 785-805.

14 Rorvik K, Husby P, Gramstad L, Vamnes JS, BitschLarsen $L$, Koller $M E$. Comparison of large dose of vecuronium with pancuronium for prolonged neuromuscular blockade. Br J Anaesth 1988; 61: 180-5.

15 Diefenbach $C$, Mellinghoff $H$, Grond S, Buzello $W$. Atracurium and vecuronium: repeated bolus injection versus infusion. Anesth Analg 1992; 74: 519-22.

16 Donati $F$, Bevan $D R$. Long-term succinylcholine infusion during isoflurane anesthesia. Anesthesiology 1983; 58: 6-10.

17 Martineau RJ, St-Jean B, Kitts JB, et al. Cumulation and reversal with prolonged infusions of atracurium and vecuronium. Can J Anaesth 1992; 39: 670-6.

18 Shanks $C A$, Fragen RJ, Ling $D$. Continuous intravenous infusion of rocuronium (ORG 9426) in patients receiving balanced, enflurane, or isoflurane anesthesia. Anesthesiology 1993; 78: 649-51.

19 Salib YM, Donati F, Bevan DR. Edrophonium antagonism of vecuronium at varying degrees of fourth twitch recovery. Can J Anaesth 1993; 40: 839-43.

20 Lebowitz PW, Ramsey FM, Scvarese JJ, Ali HH. Potentiation of neuromuscular blockade in man produced by combinations of pancuronium and metocurine or pancuronium and d-tubocurarine. Anesth Analg 1980; 59: 604-9.

21 Gibbs NM, Rung GW, Braunegg PW, Martin DE. The onset and duration of neuromuscular blockade using combinations of atracurium and vecuronium. Anaesth Intensive Care 1991; 19: 96-100.

22 Mirakhur RK, Gibson FM, Ferres CJ. Vecuronium and dtubocurarine combination: potentiation of effect. Anesth Analg 1985; 64: 711-4.

23 Kay B, Chestnut RJ, Sum Ping JST, Healy TEJ. Economy in the use of muscle relaxants. Anaesthesia 1987; 42: $277-80$. 


\section{Analyse coût-bénéfice pour les curares}

François Donati PhD MD FRCPC

Dans plusieurs milieux, en particulier chez les administrateurs d'hôpitaux, les politiciens et le public, on a l'impression que les coûts de la santé deviennent incontrôlables. On pointe du doigt tous les domaines de la médecine, mais surtout les spécialités à haute technologie qui évoluent rapidement, comme l'anesthésie. Cette perception d'escalade des coûts s'ajoute à une réticence de la part des gouvernements et des contribuables à augmenter leur contribution aux soins de santé pour forcer les médecins à considérer les incidences financières de leurs activités. Les professionnels de la santé n'aiment évidement pas troquer la qualité des soins pour des objectifs budgétaires, mais il est impossible d'oublier complètement le problème. Dans l'avenir, il faudra non seulement viser la sécurité et la satisfaction du patient, mais aussi rendre compte de l'utilisation de ressources devenues rares. En anesthésie, la frugalité sera à l'honneur, à moins que nous puissions justifier nos dépenses.

\section{Problématique}

\section{Les curares}

Le relâchement musculaire est une composante essentielle de l'anesthésie, et l'on administre couramment des curares pour obtenir l'immobilité du patient. Les médicaments disponibles varient énormément quant à leur coût et à leurs propriétés, de sorte que la substitution d'un agent pour un autre pourrait résulter en des économies appréciables. Cependant, les curares ne représentent qu'une petite fraction des coûts d'une intervention chirurgicale. A Ottawa,' on a rapporté que le coût des curares et des anticholinestérasiques ne représentait que $23 \%$ du budget consacré aux médicaments utilisés en anesthésie. Ceux-ci n'occupaient qu'une part de 5,7\% du budget de la pharmacie de l'hôpital, et seulement $0,3 \%$ du budget annuel de l'hôpital. Les curares utilisés en anesthésie ne représentent donc que $0,07 \%$ du budget de l'hôpital. Malgré ce petit pourcentage, il serait peu sage de dépenser avec impunité. Toutefois, avant de se rabattre systématiquement sur les produits les moins chers, il convient d'examiner l'augmentation de coûts que ce changement pourrait entraîner.

Qui paie, qui économise, qui profite?

Dans une analyse de coût-bénéfice, il faut au départ déterminer qui paie et qui profite des dépenses. Johnstone et Martinec ${ }^{2}$ ont démontré la complexité des interactions entre le patient, les professionnels, le payeur et les hôpitaux. Même dans un système où tout l'argent vient de la même source, comme c'est le cas au Canada, il n'est pas toujours facile de déterminer si une intervention fait économiser. Par exemple:

1 Des compressions dans un budget départemental pourrait se traduire par des coûts plus élevés pour un autre département. Par exemple, l'utilisation de curares à action longue de préférence aux curares à durée plus courte pourrait diminuer les coûts de pharmacie, mais les malades pourraient rester plus longtemps à la salle de réveil. Il serait difficile d'attribuer ce phénomène aux curares, et l'augmentation des coûts pourrait passer inaperçue parce que le budget de la salle de réveil est plus important que celui de la pharmacie.

2 Des économies ne peuvent se réaliser que si un grand nombre de professionnels, incluant les anesthésistes, agissent de concert. L'utilisation d'un médicament à action courte en fournit une illustration. Ce produit pourrait contribuer à accélérer le roulement dans les salles d'opérations, mais seulement si les chirurgiens, les infirmières et les préposés s'ajustent. Un autre exemple est celui de l'utilisation de curares à action courte par un seul parmi plusieurs anesthésistes. La durée moyenne du séjour en salle de réveil ne pourra diminuer beaucoup s'il est le seul à agir de cette façon.

3 Linsatisfaction du malade a un prix, mais celui-ci est rarement comptabilisé dans le bilan financier de l'hôpital. Comment, par exemple, évaluer le coût de douleurs musculaires, d'une toux peu efficace ou d'une démarche hésitante?

4 On peut économiser beaucoup en diminuant le séjour en salle d'opération ou en salle de réveil. A Winnipeg, on a dépensé $876306 \$$ pour 8458 malades à la salle de réveil, soit $103 \$$ par cas. ${ }^{3}$ On n'a pas spécifié la durée moyenne de séjour, mais il semble raisonnable de parler de $1 \$$ par minute. Le coût d'une minute en salle d'opération est encore plus élevé. Dans notre hôpital, il se situe, pour le personnel et l'entretien, à $2 \$$ par minute. Ainsi, un curare qui diminuerait de cinq minutes le temps passé en salle d'opération et de dix minutes le séjour en salle de réveil pourrait faire économiser $20 \$$ par cas. Ces économies pourraient ne rester que virtuelles si le nombre d'infirmières en salle de réveil demeure inchangé, si l'anesthésiste 
s'arrête pour siroter un autre café entre le cas, ou si le temps gagné pendant la journée ne sert qu’à écourter la journée de travail des préposés et des infirmières.

Malheureusement, on n'a pas étudié de façon systématique la problématique expliquée ci-dessus. Ainsi, il est difficile d'arriver à des conclusions fermes. Toutefois, il est utile de comparer les coûts de la curarisation et de la décurarisation.

\section{Le coût des curares}

\section{Coûts fixes}

Au Canada, le coût des médicaments administré dans un hôpital n'est pas défrayé par le patient ou par un tiers (le gouvernement). La pharmacie de l'hôpital doit acheter, stocker, quelquefois préparer, et fournir les médicaments dont les anesthésistes se servent. Ces coûts fixes ne seront pas considérés ici parce qu'ils restent essentiellement inchangés par la substitution d'un produit par un autre.

\section{Coûts de l'administration}

En anesthésie, les médicaments sont administrés par un anesthésiste qui doit se trouver au chevet du malade en tout temps. Aucune économie n'est donc engendrée en changeant la méthode ou la fréquence d'administration. Le coût des seringues et des aiguilles est négligeable par rapport à celui des médicaments (une seringue de $10 \mathrm{ml}$ et une aiguille de calibre 20 coûtent $0,10 \$$ ). Le coût des perfusions est plus élevé, mais raisonnable. Pour moins de $1 \$$, on se procure une seringue de $60 \mathrm{ml}$, la tubulure et le robinet à trois voies. L'étape la plus coûteuse dans l'administration d'un médicament est d'ouvrir l'ampoule. Un vial de $10 \mathrm{mg}$ de vécuronium coûte autant $(19,49 \$)$, qu'il soit utilisé entièrement ou en partie.

\section{Variations de coûts}

Le prix des médicaments varie, quelquefois de façon marquée, d'une année à l'autre, d'un pays à l'autre, quand ce n'est pas d'un hôpital à l'autre. Ces variations sont dues, entre autres, 1) aux conditions du marché, 2) aux achats de groupe, 3) à la concurrence, et 4) à la présence d'une copie générique. Ainsi, il faut comparer les prix à l'intérieur d'une même institution, en se basant sur les coûts payés par cette institution, et en revisant les conclusions fréquemment. Par exemple, au moment de mettre sous presse (fin 1993), le prix du pancuronium dans notre hôpital était de $6,60 \$$ pour $5 \mathrm{mg}(1,34 \$ \mathrm{le} \mathrm{mg})$. Au Kansas, on obtenait le même produit pour 1,66 \$(U.S.) pour $10 \mathrm{mg}$, soit moins de $0,17 \$\left(\right.$ U.S.) pour $1 \mathrm{mg} .{ }^{4} \mathrm{Le}$ Tableau I donne les prix des curares, en dollars canadiens, disponibles à 1'hôpital Royal Victoria à Montréal, à la fin de 1993. Il devrait donner une indication, mais une
TABLEAU I

\begin{tabular}{lcc}
\hline Produit & Quantité & Coût (sCan) \\
\hline Succinylcholine & $100 \mathrm{mg}$ & 0,88 \\
Succinylcholine (poudre) & $500 \mathrm{mg}$ & 7,34 \\
Atracurium & $100 \mathrm{mg}$ & 39,55 \\
Vécuronium & $10 \mathrm{mg}$ & 19,49 \\
Pancuronium & $5 \mathrm{mg}$ & 6,60 \\
d-Tubocurarine & $30 \mathrm{mg}$ & 1,06 \\
Doxacurium & $5 \mathrm{mg}$ & 26,15 \\
Métocurine & $40 \mathrm{mg}$ & 22,88 \\
Mivacurium & $20 \mathrm{mg}$ & $20,00^{*}$ \\
Rocuronium & $\mathrm{n} / \mathrm{d}$ & $\mathrm{n} / \mathrm{d}$ \\
Atropine & $0,6 \mathrm{mg}$ & 0,21 \\
Glycopyrrolate & $4 \mathrm{mg}$ & 10,40 \\
Néostigmine & $5 \mathrm{mg}$ & 2,06 \\
Edrophonium & $100 \mathrm{mg}$ & 5,72 \\
\hline
\end{tabular}

*Selon les prix U.S. Le médicament n'était pas disponible au Canada au moment de mettre sous presse.

indication seulement, des prix payés par d'autres hôpitaux canadiens.

\section{Coûts de la curarisation, de son entretien et de la décurarisation}

Passons maintenant aux coûts curarisation de l'administration des curares pour l'intubation trachéale et pour l'entretien de la curarisation, aussi que ceux de la décurarisation, si nécessaire, à la fin d'une intervention chirurgicale. Le coût total dépendra du produit utilisé, de la durée de l'intervention et évidemment du poids du patient.

\section{Dose dintubation}

La dose d'intubation est normalement au moins deux fois celle qui produit un bloc de $95 \%$ de l'adducteur du pouce $\left(\mathrm{DA}_{95}\right)$. On doit administrer une dose assez élevée à cause 1) de la variabilité d'un sujet à l'autre, qui fait que la $\mathrm{DA}_{95}$ n'est pas suffisante chez certains patients, ${ }^{5}$ et 2) de la résistance relative des muscles laryngés ${ }^{6}$ et respiratoires $^{7}$ aux curares. Le Tableau II présente la $\mathrm{DA}_{95}{ }^{8-12}$ des produits curarisants disponibles au Canada et leur coût pour un malade de $70 \mathrm{~kg}$. La succinylcholine est le produit le moins coûteux, mais elle a des effets secondaires. L'utilisation d'une dose défasciculante d'un curare non-dépolarisant augmente, mais de peu, ${ }^{9}$ le coût de la curarisation pour l'intubation. Parmi les curares non-dépolarisants, seule la d-tubocurarine demeure peu coûteuse. Toutefois, la plupart des cliniciens seraient réticents à utiliser de telles doses de d-tubocurarine, à cause de son potentiel histamino-libérateur. De façon générale, l'inconvénient majeur des curares à action longue est que leur durée d'action est souvent supérieure à celle de l'intervention chirurgicale. De plus, la décurarisation est parfois très difficile à obtenir. 5,13 
TABLEAU II

\begin{tabular}{llll}
\hline Produit & $\begin{array}{l}D A_{95} \\
\left(m g \cdot \mathrm{kg}^{-1}\right)\end{array}$ & $\begin{array}{l}2 \times D A_{95} \text { pour 70 } \mathrm{kg} \\
(\mathrm{mg})\end{array}$ & $\begin{array}{l}\text { Coût } \\
\text { (\$Can) }\end{array}$ \\
\hline $\begin{array}{l}\text { Succinylcholine } \\
\text { d-Tubocurarine plus }\end{array}$ & 0,5 & 70 & 0,62 \\
$\quad$ succinylcholine & 1,0 & $140(+3 \mathrm{mg} \mathrm{dTC})$ & 1,55 \\
Atracurium & 0,25 & 35 & 13,84 \\
Vécuronium & 0,05 & 7 & 13,64 \\
Pancuronium & 0,07 & 10 & 13,20 \\
d-Tubocurarine & 0,4 & 50 & 1,99 \\
Doxacurium & 0,03 & 4,2 & 21,94 \\
Métocurine & 0,2 & 14 & 16,02 \\
Mivacurium & 0,1 & 14 & $14,00^{*}$ \\
Rocuronium & 0,3 & 42 & $\mathrm{n} / \mathrm{d}$ \\
\hline
\end{tabular}

*Selon les prix U.S. Le médicament neetait pas disponible au Canada au moment de mettre sous presse.

\section{Entretien de la curarisation}

Le moment où il faut réinjecter un curare dépend de la durée d'action du curare administré pour l'intubation. Si celui-ci est la succinylcholine, il faut redonner une dose de charge après 5 à $15 \mathrm{~min}$, soit lorsque la fonction neuromusculaire récupère. Si l'on poursuit la curarisation avec un curare non-dépolarisant, on a besoin de donner une $\mathrm{DA}_{95}$. Le mivacurium a une duré d'action de l'ordre de 15 à 25 min. ${ }^{10}$ Lorsque l'atracurium, le vécuronium ou le rocuronium sont utilisés pour l'intubation, on obtiendra un bloc de $90 \%$ ou plus pendant 20 à 50 min. ${ }^{14,15}$ Les curares à action longue, donnés en doses équipotentes, auront une durée d'action de 30 à $180 \mathrm{~min} .{ }^{14} \mathrm{La}$ quantité de curare nécessaire à l'entretien de la curarisation à partir du moment où la récupération est entamée est présentée au Tableau III. 10,15-18 $^{-18}$

\section{Décurarisation}

On donne souvent une dose unique d'anticholinestérasique pour tous les malades. Le coût des mélanges les plus fréquemment utilisés apparait au Tableau IV. Il faut rappeler toutefois que ces doses, et même des doses plus importantes, ne sont pas efficaces si le bloc est trop profond, ${ }^{5,13}$ et que des doses plus faibles peuvent être tout aussi efficaces en présence d'un bloc léger. ${ }^{19}$

\section{Coûts totaux de la curarisation-décurarisation}

Le coût de la curarisation et de la décurarisation dépend du produit utilisé et de la durée de lintervention. On doit tenir compte non seulement du prix du produit, mais aussi de sa prévisibilité et de ses effets secondaires. L'effet des curares est variable. Une dose donnée peut produire une durée d'action aussi courte que celle associée normalement à la moitié de la dose, ou encore aussi longue que celle du double de la dose. Ainsi, $10 \mathrm{mg}$ de pancuronium pourrait ne durer que $30 \mathrm{~min}$, soit la durée
TABLEAU III

\begin{tabular}{llcc}
\hline & \multicolumn{2}{l}{ Vitesse dinfusion } & $\begin{array}{l}\text { Coût pour } 70 \\
\mathrm{~kg} \text { par heure }\end{array}$ \\
\cline { 2 - 3 } Produit & $\left(\mu \mathrm{g} \cdot \mathrm{kg}^{-1} \cdot \mathrm{min}^{-1}\right)\left(\mathrm{mg} \cdot \mathrm{hr}^{-1}\right)$ & (San) \\
\hline Succinylcholine & 100 & 420 & 6,17 \\
Atracurium & 5 & 21 & 8,31 \\
Vécuronium & 1 & 4,2 & 8,19 \\
Rocuronium & 7 & 29,4 & $\mathrm{n} / \mathrm{d}$ \\
Mivacurium & 7 & 29,4 & $29,40^{*}$ \\
Pancuronium & 0,4 & 1,7 & 2,24 \\
d-Tubocurarine & 3 & 12,6 & 0,45 \\
Métocurine & 1,5 & 6,3 & 3,60 \\
Doxacurium & 0,15 & 0,63 & 3,29 \\
\hline
\end{tabular}

*Selon les prix U.S. Le médicament n'était pas disponible au Canada au moment de mettre sous presse.

TABLEAU IV

\begin{tabular}{lll}
\hline & $\begin{array}{l}\text { Dose } \\
(\text { pour un sujet de 70 kg) } \\
(\mathrm{mg})\end{array}$ & $\begin{array}{l}\text { Coût } \\
\text { (SCan) }\end{array}$ \\
\hline Produits & $1,2-2,5$ & 1,45 \\
Atropine-néostigmine & $0,6-2,5$ & 2,59 \\
Glycopyrrolate-néostigmine & 1,93 \\
\hline Atropine-edrophonium & $0,6-30$ & \\
\hline
\end{tabular}

d'action moyenne produite par $5 \mathrm{mg}$, ou avoir un effet qui se prolonge pendant $180 \mathrm{~min}$, comme pour une dose de $20 \mathrm{mg}$. Les curares à action courte ou intermédiaire (atracurium, vécuronium et mivacurium) sont plus prévisibles que les curares à action plus longue, puisque doubler la dose des premiers n'entraine qu'une légère prolongation du bloc. Au Tableau V, on compare les coûts pour des interventions plus ou moins longues. La technique la moins coûteuse pour les interventions courtes demeure la succinylcholine en bolus suivie d'une perfusion. Pour des interventions plus longues, il est préférable de maintenir la curarisation avec un curare à action longue après une intubation facilitée par la succinylcholine. Il faut toutefois tenir compte des effets secondaires de la succinylcholine, des effets cardiovasculaires des curares à longue durée et des problèmes de décurarisation que ceuxci entrainent.

\section{Gestion des coûts}

La curarisation ne constitue qu'une partie infime des coûts de l'hospitalisation. Si l'on a besoin d'un curare, il vaut mieux l'administrer. Toutefois, quelques mesures pourraient aider à restreindre les coûts:

1 Eviter le gaspillage. Un médicament inutilisé ne profite à personne. Les produits coûteux doivent donc être préparés immédiatement avant leur utilisation, en quantité suffisante, mais limitée. Une seringue de 10 
TABLEAU V Coûts typiques pour un patient de $70 \mathrm{~kg}$ (I: induction; E: entretien; D: décurarisation)
Durée: $30 \mathrm{~min}$
I: $\quad$ TTC (3 mg), succinylcholine ( $140 \mathrm{mg})$
E: Succinylcholine $(200 \mathrm{mg})$
D: Nil
I: $\quad$ dTC $(3 \mathrm{mg})$, succinylcholine $(140 \mathrm{mg})$
E: Vécuronium $(3 \mathrm{mg})$ ou atracurium $(15 \mathrm{mg})$
D: Atropine $(1,2 \mathrm{mg})$, néostigmine $(2,5 \mathrm{mg})$
I: Vécuronium $(7 \mathrm{mg})$ ou atracurium $(35 \mathrm{mg})$
E: Nil
D: Atropine (1,2 mg), néostigmine (2,5 mg)

(N.B. La durée d'action du vécuronium ou de l'atracurium sera souvent plus longue que celle de l'intervention.)
Durée: $60 \mathrm{~min}$
I: dTC (3 mg), succinylcholine (140 mg)
E: Succinylcholine $(500 \mathrm{mg})$
D: Nil
I: $\quad$ dTC ( $3 \mathrm{mg})$, succinylcholine $(140 \mathrm{mg})$
E: Vécuronium $(5 \mathrm{mg})$ ou atracurium $(25 \mathrm{mg})$
D: Atropine $(1,2 \mathrm{mg})$, néostigmine $(2,5 \mathrm{mg})$
I: Vécuronium (7 mg), ou atracurium $(35 \mathrm{mg})$
E: Vécuronium $(2 \mathrm{mg})$, ou atracurium $(10 \mathrm{mg})$
D: Atropine $(1,2 \mathrm{mg})$, néostigmine $(2,5 \mathrm{mg})$
I: $\operatorname{dTC}(3 \mathrm{mg})$, succinylcholine $(140 \mathrm{mg})$
E: Pancuronium $(5 \mathrm{mg})$
D: Atropine $(1,2 \mathrm{mg})$, néostigmine $(2,5 \mathrm{mg})$

(N.B. La décuraristion après le pancuronium pourrait être incomplète.)

Durée: $120 \mathrm{~min}$

I: dTC (3 mg), succinylcholine (140 mg)

E: Succinylcholine $(1200 \mathrm{mg})$

D: Atropine ( $1,2 \mathrm{mg})$, néostigmine $(2,5 \mathrm{mg})$

I: dTC (3 mg), succinylcholine (140 mg)

E: Vécuronium $(10 \mathrm{mg})$ ou atracurium $(50 \mathrm{mg})$

$\mathrm{D}$ : Atropine (1,2 mg), néostigmine (2,5 $\mathrm{mg})$

I: Vecuronium (7 mg), ou atracurium (35 mg)

E: Vecuronium ( $7 \mathrm{mg}$ ), ou atracurium ( $35 \mathrm{mg}$ )

D: Atropine (1,2 $\mathrm{mg})$, néostigmine $(2,5 \mathrm{mg})$

I: dTC (3 mg), succinylcholine (140 mg)

E: Pancuronium $(7 \mathrm{mg})$

D: Atropine $(1,2 \mathrm{mg})$, néostigmine $(2,5)$

I: $\operatorname{dTC}(3 \mathrm{mg})$, succinylcholine (140 mg)

E: $\mathrm{dTC}(30 \mathrm{mg})$

D: Atropine (1,2 mg), néostigmine $(2,5 \mathrm{mg})$

I: Pancuronium $(10 \mathrm{mg})$

E: Nil

D: Atropine (1,2 mg), néostigmine (2,5 mg)

I: $\operatorname{dTC}(3 \mathrm{mg})$, succinylcholine (140 $\mathrm{mg}$ )

E: Doxacurium $(2,5 \mathrm{mg})$

D: Atropine (1,2 mg), néostigmine (2,5 mg)

(N.B. La decurarisation après le pancuronium, la dTC, ou le doxacurium pourrait être incomplète.) ml et une aiguille de calibre 20 coûtent seulement 0,10 $\$$. Il est souvent avantageux de répartir de contenu d'une ampoule dans plusieurs seringues.

2 Ne donner que le nécessaire. Normalement, il est inutile de curariser au delà d'un twitch visible (bien surveiller!). On a besoin de peu ou pas de curarisation pour certaines interventions, comme celles impliquant la peau et les membres. Les curares sont inefficaces si la chirurgie se fait à l'aide d'un garrot (le médicament ne se rend pas là où il doit aller!).

\section{Pierres d'achoppement}

Quelquefois, les bonnes intentions n'aboutissent pas à des résultats probants. Par exemple:

1 Potentialisation de deux curares. Utilisés ensemble, certains curares se potentialisent, comme par exemple le pancuronium et la métocurine. ${ }^{20}$ En dépit d'une diminution appréciable de produit nécessaire, le prix élevé de la métocurine rend cette solution peu intéressante. Le pancuronium et la d-tubocurarine sont aussi mutuellement potentialisateurs, ${ }^{20}$ mais le prix élevé du pancuronium .rend le mélange plus coûteux que la $\mathrm{d}$ tubocurarine utilisée seule. L'atracurium et le vécuronium ont peut-être un léger effet potentialisateur l'un sur l'autre, ${ }^{21}$ mais les études ne sont pas unanimes. Enfin, la d-tubocurarine et le vécuronium forment un mélange potentialisateur, ${ }^{22}$ mais on ignore si la décurarisation est aussi rapide qu'avec la vécuronium seul.

2 Curare à action longue après curare à action courte. Lorsque l'intervention s'avère plus longue que prévu, on est tenté de donner, par exemple, du pancuronium après le vécuronium. Le curare à action " longue " a alors une durée d'action semblable à celle du curare à durée plus courte. ${ }^{23}$ Ainsi, l'économie réalisée est presque nulle si les deux produits ont des prix semblables.

3 Se restreindre aux produits à action longue. Les vieux curares à action longue, dont les prix sont bas, peuvent entraîner plus de problèmes que les économies qu'ils produisent. Une curarisation résiduelle fréquente, ${ }^{5,13}$ leur imprévisibilité et l'impossibilité de produire une curarisation profonde sont leurs inconvénients majeurs.

4 Ne pas décurariser. Le prix du mélange néostigmineglycopyrrolate aux doses habituelles n'est que de 2,59 \$, encore moins si l'on substitue l'atropine. Si la décurarisation spontanée est bien engagée, on peut réduire les doses d'anticholinestérasique. Toutefois, si l'on considère le coût élevé d'une dépression respiratoire, la décurarisation pharmacologique est de mise, à moins que l'on ait établi de façon non-équivoque qu'il n'y a pas de curarisation résiduelle.

$5 \mathrm{Ne}$ pas curariser. Les agents anesthésiques intraveineux ou par inhalation ont des effets cardiovasculaires plus 
importants que les curares les plus récents. En l'absence de curare, on donne généralement plus de produits intraveineux ou volatils, ce qui peut augmenter les coûts et retarder l'éveil.

\section{Conclusion}

Actuellement, le prix des curares est trop faible, comparativement aux coûts de l'anesthésie, de la chirurgie et de l'hospitalisation pour recommander leur utilisation restreinte pour des raisons budgétaires. L'administration systématique de curares à action longue au lieu des curares à action courte, plus coûteux, peut entraîner des problèmes importants. Toutefois, on pourrait réaliser des économies substantielles en évitant le gaspillage et la curarisation excessive.

\section{Références}

(Voir page $\mathrm{R} 7$ ) 